Annals of Warsaw University of Life Sciences - SGGW

Land Reclamation No 46 (4), 2014: 291-300

(Ann. Warsaw Univ. Life Sci. - SGGW, Land Reclam. 46 (4), 2014)

\title{
Applying the coagulation and reverse osmosis for water recovery from evaporative water
}

\author{
MAGDALENA M. MICHEL ${ }^{1}$, LIDIA RECZEK ${ }^{1}$, TADEUSZ SIWIEC ${ }^{1}$, \\ PIOTR RUDNICKI ${ }^{2}$ \\ ${ }^{1}$ Department of Civil Engineering, Warsaw University of Life Sciences - SGGW \\ ${ }^{2}$ ChemTech Company
}

\begin{abstract}
Applying the coagulation and reverse osmosis for water recovery from evaporative water. Evaporative water from the concentration of yeast slurry is a potential raw material for water recovery. It is characterized by low $\mathrm{pH}(4.6-6.3)$, increased turbidity (3.65-13.7 NTU), and high content of total organic carbon (356-754 mg/L). Its treatment in the volume coagulation process using $\mathrm{NaOH}$ and coagulant PIX 111, was studied. Water turbidity was lowered to a value below 1 NTU, but coagulation did not allow for the removal of organic compounds. Coagulation was effective at temperatures of 20 and $40^{\circ} \mathrm{C}$. Pre-treatment of the feed water for RO included alkalization, coagulation, sedimentation, and $5 \mu \mathrm{m}$ fine filtration (variant I), as well as single $5 \mu \mathrm{m}$ fine filtration (variant II as a blank). In variant I the feed with improved properties was achieved. Membrane filtration allowed for effective desalination of evaporative water, 98 and $73 \%$ conductivity retention was obtained, depending on the method of the feed pre-treatment. The organic compounds were removed less efficiently, at 94 and $84 \%$, respectively.
\end{abstract}

Key words: water recovery, evaporative water, coagulation, reverse osmosis

\section{INTRODUCTION}

According to data from the Central Statistical Office, water consumption for production purposes in Poland in 2013 accounted for $71 \%$ of the total water consumption for the national economy and population (Statistical Yearbook, 2013a). This is a large amount, therefore, to reduce the consumption of water in a view of this material deficit, is a challenge to the industry. The solution can be a water recovery and creation of closed water cycles. The positive fact is that in Poland $41.6 \%$ of industrial plants consuming water for the production, are equipped with a closed or semi-closed water cycles (Statistical Yearbook, 2013b). In many sectors of the food industry, there is a great potential for applying the water recovery, however, it requires to develop and implement the Hazard Analysis and Critical Control Point (HACCP) procedures to identify the risks and to determine the ways for their monitoring (Casani et al., 2005).

Environmental and financial benefits from the reduction of water consumption are often perceived by large companies, where investments in water saving quickly return. For example, a set of activities carried out in KP Brewery in Poznań allowed to reduce water consumption by the plant to $3.1 \mathrm{~L}$ per 
$1 \mathrm{~L}$ of beer (Czeszewski, 2010). Another example of pro-environmental activities is the research on the recovery of water from evaporative processes in the food industry. Based on the RO membrane separation, ion exchange, and sorption on activated carbon, a technology was developed that allows to recover the water from the process of fruit juice concentration (Marjanowski et al., 2010). Similarly, RO process was applied to an efficient treatment of dairy wastewater for its re-use as a source of water for the same applications as heating, cleaning and cooling (Vourch et al., 2007).

Evaporative water is a potential raw material for the recovery of water. The aim of the study was to investigate the suitability of the coagulation and reverse osmosis processes to purify the evaporative water to a level enabling its reuse in the industry. The order of studied processes resulted from the fact that water purification in the membrane separation process, in particular reverse osmosis, is directly related to the development of the technology solutions for preparing the feed water.

\section{MATERIAL AND METHODS}

\section{Characteristic of evaporative water}

The research material consisted of evaporative water samples collected from the technological line of the facility performing the concentration of yeast slurry, that is the production waste from brewery. In the analyzed production plant, share of evaporative water in the total water from production (wastewater) is high and amounts to about $70 \%$ (i.e. 60-70 $\mathrm{m}^{3}$ daily). Before choosing a treatment processes, an analysis of physico-chemical composition of evaporative water was carried out. To this, five random water samples were collected from the retention reservoir during the period of 2 months.

\section{Coagulation experiment}

Prior to the actual research, two preliminary tests were performed. One consisted in verifying the effectiveness of a lime as the agent alkalizing the water and increasing its alkalinity, while the second in setting the order of coagulant and alkalizing agent dosage. Although the lime proved to be a very good means for water alkalizing in technological terms, its use was given up, because the facility was not able to mount the saturator, lime milk solution tank, and lime water tank. Therefore, the process was limited to the use of $\mathrm{NaOH}$ only. In the case of the other experiment, it was demonstrated that improved effects can be achieved by alkalizing the solution prior to dosing the coagulant rather than vice versa. The scope of the effective coagulant dose was also determined, which was $0.03-0.05 \mathrm{~L} / \mathrm{m}^{3}$. On the basis of above information, the study method was developed.

The study was conducted on a laboratory scale using evaporative water samples of $0.5 \mathrm{~L}$ volume. To increase the water alkalinity, $\mathrm{NaOH}$ was used. 
Commercial formulation PIX 111 (iron (III) chloride) was applied as the coagulant. The ferric coagulant was used in the tests because the residual iron is more easily removed from the membrane surface during its washing than the residual aluminum. Evaporative water was subject to volume coagulation in the coagulator equipped with a paddle stirrer with adjustable speed of rotation. For one minute from the coagulant dosing fast mixing (150 rpm) was applied. Then slow stirring was performed (10 rpm) for a period of 5-15 min depending on the intensity of the flocculation process. The experiment was carried out at temperatures of 20 and $40^{\circ} \mathrm{C}$. After 10 min of sedimentation, the supernatant liquid was filtered on a paper filter type 389 . The purification effectiveness evaluation was performed by comparing the physico-chemical properties of raw evaporative water and filtrates.

\section{Reverse osmosis experiment}

The study was conducted on a semi-technical scale using evaporative water samples of $900 \mathrm{~L}$ volume. The study included two experiments, which differed in methods of the feed pre-treatment, whereas the membrane separation process was carried out uniformly. Experiments were carried out at $40 \pm 3^{\circ} \mathrm{C}$.

In the first variant (I), the pre-treatment consisted in the increasing the water alkalinity to $1.7 \mathrm{mval} / \mathrm{L}$ by means of $\mathrm{NaOH}$, and coagulation using PIX 111 at the rate of $0.03 \mathrm{~L} / \mathrm{m}^{3}$. These parameters were determined in a previous experiment with coagulation. After sedimentation of the flocks, the supernatant was filtered through a 10" polypropylene depth filter with a $5 \mu \mathrm{m}$ cut. The polypropylene depth filter was applied, because similar string wound can be ineffective in the colloid removal from gray water (Malarski, 2013). Filtration parameters: efficiency $1 \mathrm{~m}^{3} / \mathrm{h}$, pressure 2 bar. This gave a sample of $700 \mathrm{~L}$, which was the feed for the RO process.

In the second variant (II), pre-treatment consisted in filtering the raw evaporative water through 10 " polypropylene depth filter with a $5 \mu \mathrm{m}$ cut. Filtration parameters: efficiency $1 \mathrm{~m}^{3} / \mathrm{h}$, pressure 2 bar. Filtrate of $700 \mathrm{~L}$ volume was the feed for the RO process.

Membrane filtration of both feed samples was carried out on RO membrane of AG-90 type manufactured by General Electric Company. The spiral-wound industrial element was applied with active area of the membrane $8.4 \mathrm{~m}^{2}$ and following operational parameters: average permeate flow $0.35 \mathrm{~m}^{3} / \mathrm{h}$, average permeate flux $0.041 \mathrm{~m}^{3} /\left(\mathrm{m}^{2} \cdot \mathrm{h}\right)$, maximum temperature for continuous operation $50^{\circ} \mathrm{C}$, typical operating pressure 13.8 bar, $\mathrm{pH}$ range for continuous operation 4.0-11.0, turbidity of feed water below 1 NTU (GE marketing materials). Studies upon evaporative water treatment was performed at the permeate flow $0.33 \mathrm{~m}^{3} / \mathrm{h}$, feed water flow $0.85 \mathrm{~m}^{3} / \mathrm{h}$, temperature $40^{\circ} \mathrm{C}$ and operating pressure 10 bar. During the 
experiment the permeate flux was constant at $0.039 \mathrm{~m}^{3} /\left(\mathrm{m}^{2} \cdot \mathrm{h}\right)$. Prior to the experiment, membrane was launched using a tap water. Filtration of the evaporative water was carried out in a concentrating system, in which the concentrate is discharged into the tank with the feed. Finally, $500 \mathrm{~L}$ permeate and $200 \mathrm{~L}$ concentrate was achieved. The degree of the feed water concentration was determined by the $V C R$ (volume concentration ratio) factor calculated from the formula:

$$
V C R=\frac{V_{f}}{V_{f}-V_{p}}
$$

where:

$V_{f}$ - feed water volume $\left[\mathrm{m}^{3}\right]$;

$V_{p}$ - permeate volume $\left[\mathrm{m}^{3}\right]$.

Evaluation of the purification efficiency was based on the comparison of physico-chemical properties of the feed and permeate.

\section{Analytical methods}

The study of physico-chemical parameters of water in the subsequent treatment steps were carried out using the following analytical methods (Clesceri et al., 1999): $\mathrm{pH}$ - electrometric method; total alkalinity - potentiometric titration method; conductivity - conductometric method; turbidity - nephelometric method; total organic carbon (TOC) - non-purgeable organic carbon (NPOC) method; total iron - air/acetylene flame atomic absorption spectrophotometry method (AAS). Chemical oxygen demand $(C O D)$ was measured using colorimetric method and reactor digestion procedure 8000 (Hach Lange working proceders, 2008). The water was characterized by a raised temperature and the physico-chemical analyses were carried out after its cooling to the room temperature.

\section{RESULTS AND DISCUSSION}

\section{Characteristic of evaporative water}

The results of studies on physico-chemical properties of evaporative water are shown in Table 1. The values in columns refer to the relevant sample numbers. Evaporative water is characterized by slightly acidic $\mathrm{pH}$, and the differences between particular samples are quite large ( $\mathrm{pH} 4.6-6.3)$. Alkalinity is a relat-

TABLE 1. Physico-chemical properties of evaporative water from concentration of yeast slurry

\begin{tabular}{|l|c|c|c|c|c|c|}
\hline \multirow{2}{*}{ Parameter } & \multirow{2}{*}{ Unit } & \multicolumn{5}{|c|}{ Samples } \\
\cline { 3 - 7 } & & 1 & 2 & 3 & 4 & 5 \\
\hline Hydrogen ions & $\mathrm{pH}$ & 6.1 & 6.1 & 6.3 & 4.6 & 4.8 \\
\hline Alkalinity & $\mathrm{mval} / \mathrm{L}$ & 1.1 & 1.2 & 1.2 & 0.58 & 0.46 \\
\hline Conductivity & $\mu \mathrm{S} / \mathrm{cm}$ & 205 & 167 & 166 & 108 & 78.5 \\
\hline Turbidity & $\mathrm{NTU}$ & 13.7 & 8.45 & 9.46 & 3.65 & 5.21 \\
\hline Total organic carbon & $\mathrm{mg} / \mathrm{L}$ & 298 & 150 & 141 & 120 & 100 \\
\hline Chemical oxygen demand & $\mathrm{mg} / \mathrm{L}$ & 754 & 430 & 421 & 403 & 356 \\
\hline
\end{tabular}


ed parameter, which in the tested samples was low. Conductivity of evaporative water is highly variable, which may be due to the variable share of tap water from the pump cooling in its content. The share of tap water stream was estimated up to $10 \%$. Evaporative water is turbid, although low values of this parameter indicate a small amount of suspended solids. However, they contain high and varying amounts of organic compounds measured as chemical oxygen demand $(C O D)$ and total organic carbon (TOC). The diversity of the organic compounds types is quite large as evidenced by high $C O D$ to $T O C$ ratio, which is in the range of 2.5-3.6. The reason for this is very diverse composition of the yeast slurry, from which the water is generated. The organic compounds present in evaporative water are mainly sugars, proteins, ethyl alcohol, higher orders alcohols, as well as aldehydes and fusels. Evaporative water, before the reuse as make-up water, requires removal of suspended substances and lower concentrations of organic compounds.
Based on the analysis of physico-chemical composition of evaporative water, a decision to apply the coagulation process to remove the suspended particles and colloids and the process of reverse osmosis to remove dissolved substances, including primarily organic compounds, was made.

\section{Coagulation experiment}

Coagulation is a process facilitating the removal of colloids and fine suspensions from water. It requires the use of chemicals (coagulants) that by lowering the electro-kinetic potential of dispersed phase allow agglomeration its particles (Anielak, 2002, Kowal and Świderska-Bróż, 2009). Table 2 presents the effect of evaporative water coagulation at varying doses of alkali correcting the water alkalinity to the values of $1.5,1.7$, and $2.3 \mathrm{mval} / \mathrm{L}$. A characteristic feature of coagulants is water acidifying properties and use of its natural alkalinity. For this reason, $\mathrm{pH}$ adjustment was used.

TABLE 2. Effect of pre-treatment of evaporative water (coagulation experiment) at $20^{\circ} \mathrm{C}$

\begin{tabular}{|c|c|c|c|c|c|c|c|c|c|c|c|}
\hline \multirow{4}{*}{ Parameter } & \multirow{4}{*}{ Unit } & \multirow{4}{*}{$\begin{array}{c}\text { Evap- } \\
\text { orative } \\
\text { wastewa- } \\
\text { ter }\end{array}$} & \multicolumn{9}{|c|}{ Alkalis dose $\left[\mathrm{g} / \mathrm{m}^{3}\right]$} \\
\hline & & & \multicolumn{3}{|c|}{7} & \multicolumn{3}{|c|}{14} & \multicolumn{3}{|c|}{25} \\
\hline & & & \multicolumn{9}{|c|}{ Coagulant dose $\left[\mathrm{L} / \mathrm{m}^{3}\right]$} \\
\hline & & & 0 & 0.03 & 0.05 & 0 & 0.03 & 0.05 & 0 & 0.03 & 0.05 \\
\hline $\begin{array}{l}\text { Hydrogen } \\
\text { ions }\end{array}$ & $\mathrm{pH}$ & 6.3 & 7.0 & 6.3 & 6.2 & 8.0 & 6.8 & 6.4 & 9.0 & 8.6 & 8.3 \\
\hline Alkalinity & $\mathrm{mval} / \mathrm{L}$ & 1.2 & 1.5 & 1.2 & 1.0 & 1.7 & 1.4 & 1.2 & 2.2 & 1.9 & 1.8 \\
\hline Conductivity & $\mu \mathrm{S} / \mathrm{cm}$ & 166 & 178 & 200 & 206 & 181 & 210 & 218 & 188 & 225 & 257 \\
\hline Turbidity & NTU & 9.46 & 9.35 & 0.210 & 0.264 & 10.0 & 0.128 & 0.169 & 9.55 & 0.189 & 0.172 \\
\hline $\begin{array}{l}\text { Total organic } \\
\text { carbon }\end{array}$ & $\mathrm{mg} / \mathrm{L}$ & 141 & 140 & 131 & 128 & 139 & 128 & 125 & 140 & 130 & 125 \\
\hline Iron & $\mathrm{mg} / \mathrm{L}$ & 0.08 & 0.07 & 0.14 & 0.22 & 0.08 & 0.14 & 0.20 & 0.08 & 0.11 & 0.13 \\
\hline
\end{tabular}


With the increase in alkalinity, time of flocculation stage decreased, so that the flocks were formed in respectively 15 , 10 , and $5 \mathrm{~min}$ of slow stirring. Shortening the flocculation stage is advantageous and facilitates the process under operational conditions. Proportional decrease in water acidity was recorded after the coagulation process, the more that applied coagulant belongs to a group of non-hydrolyzed ones. It should also be in mind that too alkaline water after coagulation requires additional adjustment using acidifying substance. The content of residual iron in water was the lowest in samples with the highest alkalinity and close to the value of $0.1 \mathrm{mg} / \mathrm{L}$, that is recommended when running the RO membranes. For all samples, an increase in the conductivity resulting from an increase in salinity after addition of electrolytes $\mathrm{NaOH}$ and PIX 111, was observed. All used reagent doses allow very efficient reduction of turbidity, well below 1 NTU, which is very advantageous in that it protects $\mathrm{RO}$ membranes against fouling. Turbidity reduction was at a level of $98 \%$, while reduction of organic com- pounds concentrations expressed as TOC amounted to only $7-11 \%$. This indicates a high proportion of organic compounds in the dissolved phase, which cannot be removed by coagulation.

Coagulation process is dependent on the temperature, the growth of which increases its efficiency (Kowal and Świderska-Bróż, 2009). Evaporative water stored in the reservoir is characterized by a high temperature of about $70^{\circ} \mathrm{C}$, which may be advantageous for the process. However, water at such high temperature cannot be supplied on the membrane elements. The maximum temperature for continuous operation RO spiral wound elements is $50^{\circ} \mathrm{C}$, so the temperature of evaporative water must be reduced by cooling in the heat exchanger. For this reason, in the experiment two temperatures $\left(20\right.$ and $\left.40^{\circ} \mathrm{C}\right)$ below the maximum value were set. The results of studies carried out at $20^{\circ} \mathrm{C}$ and $40^{\circ} \mathrm{C}$ are shown in Tables 2 and 3 respectively. At both temperatures the effect of evaporative water treatment was equal, the turbidity in water was very efficiently reduced below 1 NTU. There-

TABLE 3. Effect of pre-treatment of evaporative water (coagulation experiment) at $40^{\circ} \mathrm{C}$

\begin{tabular}{|c|c|c|c|c|}
\hline \multirow{3}{*}{ Parameter } & \multirow{3}{*}{ Unit } & \multirow{3}{*}{$\begin{array}{l}\text { Evaporative } \\
\text { wastewater }\end{array}$} & \multirow{2}{*}{\multicolumn{2}{|c|}{$\begin{array}{l}\text { Alkalis dose } 14\left[\mathrm{~g} / \mathrm{m}^{3}\right] \\
\text { Coagulant dose }\left[\mathrm{L} / \mathrm{m}^{3}\right]\end{array}$}} \\
\hline & & & & \\
\hline & & & 0.03 & 0.05 \\
\hline Hydrogen ions & $\mathrm{pH}$ & 6.3 & 6.8 & 6.3 \\
\hline Alkalinity & $\mathrm{mval} / \mathrm{L}$ & 1.2 & 1.3 & 1.1 \\
\hline Conductivity & $\mu \mathrm{S} / \mathrm{cm}$ & 166 & 207 & 223 \\
\hline Turbidity & NTU & 9.46 & 0.167 & 0.123 \\
\hline Total organic carbon & $\mathrm{mg} / \mathrm{L}$ & 141 & 125 & 123 \\
\hline Iron & $\mathrm{mg} / \mathrm{L}$ & 0.08 & 0.11 & 0.18 \\
\hline
\end{tabular}


fore, a conclusion can be drawn that the reduction of temperature of evaporative water from 70 to $40^{\circ} \mathrm{C}$ is sufficient - the coagulation process run properly, though slightly slower flocculation was observed than at the lower temperature.

\section{Reverse osmosis experiment}

Water to be purified on the RO membranes requires pre-treatment to remove the suspensions and colloids, that cause blocking of the membrane surface (Bodzek and Konieczny, 2005, Malaeb and Ayoub, 2011). For this reason, evaporative water was subject to initial treatment. In the first variant (I), volume coagulation combined with alcalization, sedimentation and accurate filtration, was performed. There was a slower flock's growth than in the laboratory experiment, thus the flocculation duration was extended by $5 \mathrm{~min}$. As a consequence, large, lobe, and well-developed flocks that quickly sedimented, were formed. The supernatant liquid was filtered through a $5 \mu \mathrm{m}$ filter to remove fine suspended solids. The averaged sample of the filtrate was characterized by the following properties: $\mathrm{pH}$ 6.5, turbidity $0.365 \mathrm{NTU}$ and TOC $114 \mathrm{mg} / \mathrm{L}$, conductivity $162 \mu \mathrm{S} / \mathrm{cm}$. The concentration of iron remaining after the coagulation was $0.12 \mathrm{mg} / \mathrm{L}$, which was acceptable.

In a second variant (II), raw evaporative water was directly filtered by $5 \mu \mathrm{m}$ filter skipping the alkalization and coagulation processes. The averaged sample of the filtrate was characterized by the following properties: $\mathrm{pH} 4.6$, turbidity
$1.01 \mathrm{NTU}$, TOC $96.5 \mathrm{mg} / \mathrm{L}$, conductivity $78.2 \mu \mathrm{S} / \mathrm{cm}$. Its $\mathrm{pH}$ was lower than in variant $\mathrm{I}$, because alkalizing was not applied. Despite the lack of coagulation, turbidity of the water was removed, but achieved result was on the border of acceptable levels. Clarification of evaporative water applying coagulation is much more effective. The difference between the concentration of organic carbon results from its varying content in the raw water, and the efficiency of its removal in the variants I and II, was 5 and $3 \%$, respectively. The lower value of the conductivity of the product from variant II is the result of differences between samples of raw water, as well as the lack of electrolytes dosing.

On the basis of above physico-chemical properties of obtained filtrates, to treat them in the process of reverse osmosis was intended. The filtrates were the feed supplied under the pressure on the cross-flow membrane element. Changes in the concentrations of organic compounds and conductivity in the permeate are illustrated in Figures 1 and 2. When analyzing the graphs, an increase in the concentration of pollutants along with the increase of $V C R$, can be observed, which is a result of the concentration of components in the feed, to which the concentrate from the membrane is supplied. Definitely better separation effect was obtained for the feed prepared according to variant I. Lower values of components in the permeate were visible, which is probably due to the higher 


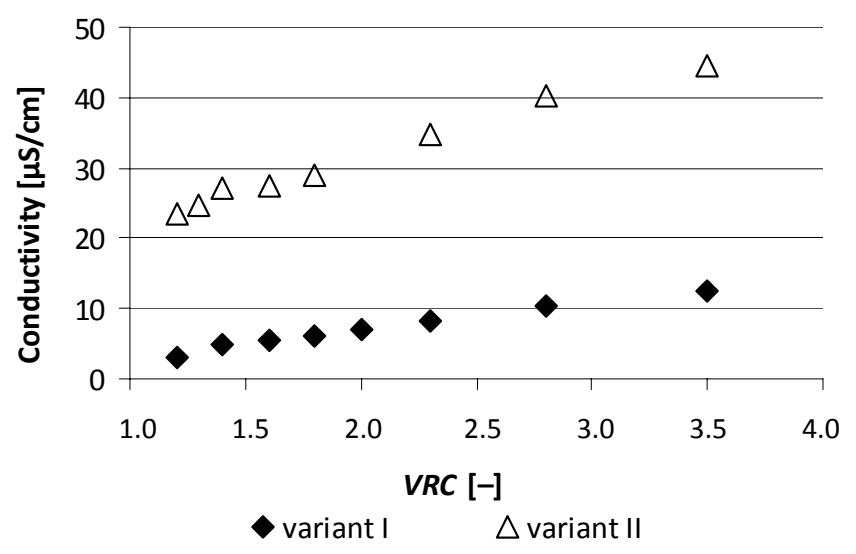

FIGURE 1. Changes in permeate conductivity as a function of the feed concentration

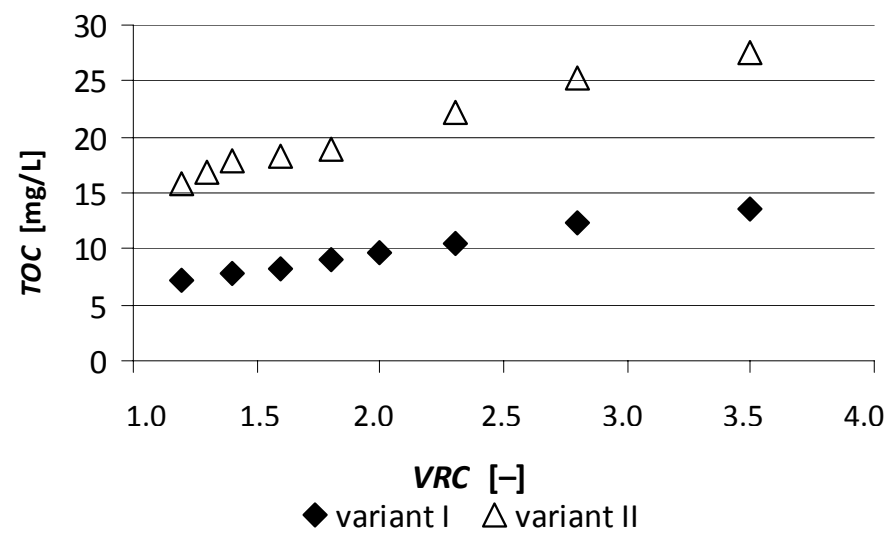

FIGURE 2. Changes in permeate TOC as a function of the feed concentration

$\mathrm{pH}$ of the feed. In variant $\mathrm{I}$, the average efficiency of salinity removal was $98 \%$ and organic compounds $94 \%$. In variant II, these values were significantly lower and amounted respectively to 73 and $84 \%$, because the acidic $\mathrm{pH}$ deteriorates the separation on the membrane.

It is important to question whether the quality of permeate obtained in the purification processes within the scope of variant I is sufficient for the reuse of water in the manufacturing plant. The level of salinity is very low and there is no doubt that water could be used up as boiler or heating water. The problem is, however, too high levels of organic components. Perhaps, water with such concentration of $T O C$ can be used in the pre-cleaning process. To get water characterized by a higher quality, concentration of organic compounds should be limited. Use a two-stage separation in 
a cascade system or a different type of membrane, e.g. high pressure RO, can be considered. Another solution is to introduce an additional process, for example, sorption or advanced oxidation, but it requires to carry out a separate study. An important element of an installation of water recovery from evaporative water should also be a protection against bio-fouling of membranes. That water is very susceptible to microbial growth as derived from the biological material (yeast slurry) and comprise a spectrum of nutrients (sugars, alcohols), as well as have a higher temperature. For this reason, it is necessary to carry out the research upon selection of an appropriate biocide inhibiting the growth of microorganisms in the system and counteracting the destruction of its elements.

\section{CONCLUSIONS}

The results indicate the usefulness of coagulation using iron salts to pretreatment of evaporative water from the concentration of yeast slurry. Applying PIX 111 coagulant, the turbidity of samples was removed with very high efficiency in both the laboratory and semi-technological experiment. A very important element of the coagulation of evaporative water is to increase its alkalinity by introducing the alkali, which determines the start of the flocculation process. Increased alkalinity accelerates flocculation as well as reduces the residual iron content remained in water after coagulation. This is a very important para- meter in the design of the technological system for evaporative water recovery. Sedimentation and $5 \mu \mathrm{m}$ fine filtration are a good solution for the removal of generated flocks to obtain water with quality that allows to supply the RO membranes. The RO membrane filtration enabled highly efficient removal of the water salinity, but it was insufficient for the removal of organic compounds, which probably dissolved in membrane material and allowed to diffuse therein. This requires further work to improve the effectiveness of their treatment in order to broaden the scope of the recovered water application.

\section{REFERENCES}

ANIELAK A.M. 2002: Chemiczne i fizykochemiczne oczyszczanie ścieków. [Chemical and physicochemical treatment of wastewater]. Wyd. Nauk. PWN, Warszawa.

BODZEK M., KONIECZNY K. 2005: Wykorzystanie procesów membranowych w uzdatnianiu wody. Oficyna Wydawnicza Projprzem-EKO, Bydgoszcz.

CASANI S., ROUHANY M., KNŘCHEL S. 2005: A discussion paper on challenges and limitations to water reuse and hygiene in the food industry. Water Research 39: 1134-1146.

CLESCERI L.S., GREENBERG A.E., EATON A.D. 1999: Standard methods for the examination of water and wastewater (20th edition). American Public Health Association, American Water Works Association and Water Environment Federation.

CZESZEWSKI K. 2010: Zwiększenie produkcji piwa przy wykorzystaniu mniejszej ilości wody na przykładzie Browaru Kompanii Piwowarskiej w Poznaniu. Przemysł Fermentacyjny i Owocowo-Warzywny 10: 19-21.

GE marketing materials (http://www.lenntech. com/Data-sheets/GE-Osmonics-AG-HR-L. pdf). 
Hach, Lange working procedures 2008. User manual DR 5000, Edition 4.

KOWAL A.L., ŚWIDERSKA-BRÓŻ M. 2009: Oczyszczanie wody. [Water purification]. Wyd. Nauk. PWN, Warszawa.

MALAEB L., AYOUB G. M. 2011: Reverse osmosis technology for water treatment: State of the art review. Desalination 267: 1-8.

MALARSKI M. 2013: Treatment of bath greywater using cartridge filters as a way to reduce water consumption in households. Ann. Warsaw Univ. of Life Sci. - SGGW, Land Reclam. 45 (1): 49-59.

MARJANOWSKI J., OSTROWSKI J., KUKIEŁKO A. 2010: Ograniczenie ilości wody zużywanej w przemyśle owocowo-warzywnym. Przemysł Fermentacyjny i Owocowo-Warzywny 5: 10-11.

Statistical Yearbook of the Republic of Poland 2013a. Central Statistical Office, Warszawa.

Statistical Yearbook of Industry - Poland 2013b. Central Statistical Office, Warszawa.

VOURCH M., BALANNEC B., CHAUFER B., DORANGE G. 2007: Treatment of dairy industry wastewater by reverse osmosis for water reuse. Desalination 219: 190-202.

Streszczenie: Zastosowanie koagulacji $i$ odwróconej osmozy do odzysku wody z wód wyparnych. Wody wyparne $\mathrm{z}$ zatężania gęstwy drożdżowej stanowią potencjalny surowiec do odzysku wody. Charakteryzują się niskim odczynem (pH 4.6-6.3), podwyższoną mętnością (3.65-13.7 NTU) i dużą zawartością ogólnego węgla organicznego (356-754 mg/L). Badano ich oczyszczanie $\mathrm{w}$ procesie koagulacji objętościowej, stosując $\mathrm{NaOH}$ oraz koagulant PIX 111. Ob- niżono mętność wody do wartości poniżej 1 NTU, jednak koagulacja nie pozwalała na usunięcie związków organicznych. Koagulacja przebiegała efektywnie w 20 i $40^{\circ} \mathrm{C}$. Oczyszczanie wstępne nadawy do RO obejmowało alkalizacje, koagulację, sedymentację i filtrację dokładną (wariant I) oraz filtrację dokładną (wariant II jako blank). W wariancie I otrzymano nadawę o lepszych właściwościach. Filtracja membranowa pozwoliła na skuteczne odsolenie wód wyparnych, uzyskano 98 i 73\% retencję przewodności w zależności od sposobu przygotowania nadawy. Związki organiczne były usuwane z mniejszą efektywnością, odpowiednio 94 i $84 \%$.

Słowa kluczowe: odzysk wody, wody wyparne, koagulacja, odwrócona osmoza

\section{MS. received August 2014}

\section{Authors' addresses:}

Magdalena M. Michel, Lidia Reczek,

Tadeusz Siwiec

Zakład Wodociagów i Kanalizacji

Wydział Budownictwa i Inżynierii Środowiska SGGW

ul. Nowoursynowska 159, 02-776 Warszawa

Poland

e-mail: magdalena_michel@sggw.pl

lidia_reczek@sggw.pl

tadeusz_siwiec@sggw.pl

Piotr Rudnicki

ChemTech

ul. Kolejowa 53, 05-092 Łomianki

Poland

e-mail: prudnicki@filtertech.com.pl 